\title{
KEWENANGAN PEMERINTAH PROVINSI SUMATERA UTARA TERKAIT PENERAPAN ASAS TANGGUNG JAWAB MUTLAK (STRICT LIABILITY) BERDASARKAN UNDANG-UNDANG NOMOR 32 TAHUN 2009 TENTANG PERLINDUNGAN DAN PENGELOLAAN LINGKUNGAN HIDUP
}

\author{
Riadhi Alhayyan', Jelly Leviza ${ }^{2}$ \\ ${ }^{1,2}$ Hukum Internasional, Fakultas Hukum, Universitas Sumatera Utara \\ Jl. Dr. T. Mansur No. 9, Padang Bulan, Medan, Sumatra Utara, Indonesia, 20155 \\ 1riadhi.alhayyan@usu.ac.id, ${ }^{2}$ jelly_lev@yahoo.co.id
}

\begin{abstract}
In general, legal protection for the environment is regulated in Act Number 32 of 2009 concerning Environmental Protection and Management (UUPPLH) and is specifically regulated in other regional regulations. Article 88 UUPPLH regulates the principle of absolute responsibility (strict liability) for environmental polluters who use B3, produce and/or manage B3 waste and/or that pose a serious threat to the environment to compensate without having to prove the element of error. The North Sumatra Provincial Government which has been delegated to the Environmental Service Office has the authority as regulated in the Governor of North Sumatera Regulation Number 33 of 2017 concerning Duties, Functions, J ob Descriptions and Work Procedures of the North Sumatra Provincial Environmental Office to carry out environmental affairs including enforcing environmental law at the provincial level as also regulated in Article 63 paragraph (2) letter (s). Environmental law enforcement can take the form of administrative sanctions, civil lawsuits and criminal charges. This research will discuss how the principle of absolute responsibility (strict liability) as regulated in the UUPPLH and how the authority of the North Sumatra Provincial Government in implementing the principle of absolute responsibility (strict liability).
\end{abstract}

Keywords: Authority, Strict Liability, North Sumatera, UUPPLH

Abstrak, Secara umum, perlindungan hukum terhadap lingkungan hidup diatur dalam UU No. 32 Tahun 2009 tentang Perlindungan dan Pengelolaan Lingkungan Hidup (UUPPLH) dan secara khusus diatur dalam peraturan daerah lainnya. Dalam pasal 88 UUPPLH diatur mengenai asas pertanggungjawaban mutlak (strict liability) bagi pelaku pencemaran lingkungan yangmenggunakan B3, menghasilkan dan/atau mengelola limbah B3 dan/atau yang menimbulkan ancaman serius terhadap lingkungan hidup untuk melakukan ganti kerugian tanpa harus membuktikan unsur kesalahan. Pemerintah Provinsi Sumatera Utara yang didelegasikan ke Dinas Lingkungan Hidup memiliki kewenangan sebagaimana yang diatur dalam Peraturan Gubernur Sumatera Utara No. 33 Tahun 2017 tentang Tugas, Fungsi, Uraian Tugas dan Tata Kerja Dinas Lingkungan Hidup Provinsi Sumatera Utara untuk melakukan urusan lingkungan hidup termasuk didalamnya melakukanpenegakan hukum lingkungan hidup pada tingkat provinsi sebagaimana juga diatur dalam Pasal 63 ayat (2) huruf (s). Pengakan hukum lingkungan tersebut dapat berupa penjatuhan sanksi admnistratif, gugatan perdata maupun penjatuhan pidana. Dalam penelitian ini akan membahas bagaimana asas tanggungjawabmutlak (strict liability) sebagaimana yang diatur dalam UUPPLH dan bagaimana 


$\begin{array}{lll}\text { Lurnas Fukum } & \text { P-ISSN } & : 2615-3416 \\ \text { Samudra Keadilan } & \text { E-ISSN } & : 2615-7845\end{array}$

Volume 15, Nomor 2, Juli-Desember 2020

kewenangan Pemerintah Provinsi Sumatera Utara dalam menerapkan asas tanggungjawab mutlak (strict liability).

Kata Kunci : Kewenangan, Strict Liability, Sumatera Utara, UUPPLH

\section{Pendahuluan}

Provinsi Sumatera Utara merupakan salah satu wilayah di Indonesia yang memiliki wilayah daratan dan lautan yang cukup luas dengan total luas wilayah sekitar 72. $981,23 \mathrm{~km}^{2}$ dan memiliki potensi sumberdaya alam yang baik. Pemanfaatan sumber daya alam seperti perkebunan, perikanan, pertambangan dan lain-lain memegang aspek penting dalam meningkatkan perekonomian di Provinsi Sumatera Utara sehingga menjaga kelestarian alam dan lingkungannya adalah tanggung jawab bersama. Sejumlah upaya-upaya dapat dilakukan salah satunya adalah dengan menegakkan hukum lingkungan.

Namun pada kenyataannya, kelestarian alam yang ada di Sumatera Utara seringkali terganggu akibat pemanfaatan sumber daya alam yang berlebihan dan tidak bertanggungjawab. Menurut Keputusan Menteri Kehutanan, Nomor 44 Tahun 2005, luas hutan di Sumatra Utara saat ini 3.742.120 hektare (ha). Yang terdiri dari Kawasan Suaka Alam/Kawasan Pelestarian Alam seluas 477.070 ha, Hutan Lindung 1.297.330 ha, Hutan Produksi Terbatas 879.270 ha, Hutan Produksi Tetap 1.035.690 ha dan Hutan Produksi yang dapat dikonversi seluas 52.760 ha.Namun angka ini sifatnya secara de jure saja. Sebab secara de facto, hutan yang ada tidak seluas itu lagi. Terjadi banyak kerusakan akibat perambahan dan pembalakan liar. Sejauh ini, sudah 206.000 ha lebih hutan di Sumut telah mengalami perubahan fungsi. Telah berubah menjadi lahan perkebunan, transmigrasi. Dari luas tersebut, sebanyak 163.000 ha untuk areal perkebunan dan 42.900 ha untuk areal transmigrasi. ${ }^{1}$ Berdasarkan data yang dihimpun oleh WALHI Sumatera Utara terkait permasalahanan lingkungan di Sumatera Utara, bencana ekologis di Sumatera Utara setiap tahunnya meningkat hampir $70 \%$ yang disebabkan buruknya pengelolaan sumber daya alam. Sehingga berdampak pada meningkatnya angka kemiskinan di Sumatera Utara.Saat ini Sumatera Utara tinggal memiliki hutan terakhir seluas $3.055 .795 \mathrm{Ha}$ yang saat ini terancam dari aktivitas industri ekstraktif seperti HTI, HPH, pertambangan serta perkebunan kelapa sawit. Selain itu, kawasan pesisir sumatera utara kondisinya saat ini kritis akibat aktivitas pertambangan pasir laut, ilegal fishing, konversi hutan mangrove menjadi perkebunan dan tambak skala besar. Berdasarkan pengolahan data oleh WALHI SUMUT luas hutan mangrove saat ini seluas 187.322,07 Ha dimana lebih dari 70\% kondisinya rusak parah. $^{2}$

Di Indonesia, penegakkan hukum lingkungan secara umum diatur dalam UU No. 32 Tahun 2009 tentang Perlindungan dan Pengelolaan Lingkungan Hidup dan

\footnotetext{
${ }^{1}$ Wikipedia, https://id.wikipedia.org/wiki/Sumatra_Utara diakses pada tanggal 01 Desember 2020

${ }^{2}$ Walhi Sumut, https://www.walhi.or.id/walhi-sumut-hari-lingkungan-hidup-sedunia-pilgubsuterburuk-sepanjang-periode, diakses pada tanggal 02 Desember 2020
} 
secara khusus diatur dalam peraturan daerah lainnya. Dalam hukum lingkungan dikenal adanya asas tanggung jawab mutlak (strict liability) dalam memintai pertanggungjawaban terhadap orang perorangan ataupun badan usaha dalam melakukan kegiatan usaha yang menyebabkan pencemaran lingkungan. Asas Tanggung Jawab Mutlak (Strict Liability) di Indonesia telah diatur dalam ketentuan Pasal 88 UU No. 32 Tahun 2009 tentang Perlindungan dan Pengelolaan Lingkungan Hidup.

TanggungJawab Mutlak (Strict Liability) adalah unsure kesalahan dimana tidak perlu dibuktikan oleh pihak penggugat sebagai dasar pembayaran ganti rugi. Ketentuanya ini merupakan lex specialis dalam gugatan tentang perbuatan melanggar hokum pada umumnya. Besarnya nilai ganti rugi yang dapat dibebankan terhadap pencemar atau perusak lingkungan hidup menurut pasal ini dapat ditetapkan sampai batas tertentu. Seiring dengan diberlakukannyaasas tanggungjawab mutlak di Indonesia maka perlu ditinjau bagaimana penerapannya di Indonesia khususnya di Provinsi Sumatera Utara. Seyogyanya, dengan adanya asas strict liability tersebut dapat membuat pelaku usaha untuk lebih lagi bertanggungjawab terhadap pelestarian lingkungan di Sumatera Utara.

Oleh karenanya, penelitian ini bertujuan untuk mengetahui bagaimana tanggungjawab mutlak (Strict Liability) dalam UU No. 32 Tahun 2009 tentang Perlindungan dan Pengelolaan Lingkungan Hidup, selanjutnya mengetahui bagaimana kewenangan Pemerintah Provinsi Sumatera Utara terkait penerapan asas tanggungjawab mutlak yang diatur dalam UU No. 32 Tahun 2009 tentang Perlindungan dan Pengelolaan Lingkungan Hidup.

\section{Metode Penelitian}

Metode penelitian ini menggunakan metode penggabungan antara penelitian hukum normatif dan empiris. Penelitian ini menggunakan menggunakan data primer dan data sekunder yang meliputi bahan hukum primer, bahan hokum sekunder dan bahan hokum tertier. Metode pengumpulan data yang digunakan dalam kajian ini diperoleh dengan cara field research (wawancara) serta melakukan studi kepustakaan (library research).

\section{Pembahasan}

\section{A. Prinsip Tanggungjawab Mutlak (Strict Liability) Dalam UU No. 32 Tahun 2009 tentang Perlindungan dan Pengelolaan Lingkungan Hidup}

Didalam UU No. 32 Tahun 2009 mengenal 2 jenis prinsip pertanggungjawaban perdata. Pertama, Prinsip Fault Based Liability yang terdapat dalam pasal 87 yaitu pertanggungjawaban berdasarkan adanya unsur kesalahan. Jadi penggugat harus membuktikan adanya unsur kesalahan tersebut. Jenis pertanggungjawaban tersebut dikenal dalam doktrin perbuatan melawan hukum (onrechtmatigedaad) yang terdapat 
dalam pasal 1365 KuhPerdata. Pembuktian adanya unsur kesalahan tersebut mensyaratkan adanya pelanggaran terhadap ketentuan ketentuan lingkungan tentang standard care (upaya minimal yang harus dilakukan dalam suatu kegiatan). Standard care itu sendiri pada umumnya dituangkan dalam bentuk suatu peraturan perundangundangan, misalnya dalam bentuk persyaratan dalam izin atau baku mutu. Adapun kelemahan dari Fault Based Liability tersebut yaitu:

a. Akibat perkembangan IPTEK sering menimbulkan kesulitan dalam memprediksi resiko yang timbul dalam suatu kegiatan industri

b. Memungkinkan pencemar atau perusak lingkungan terbebas dari pertanggungjawaban perdata jika ia dapat membuktikan telah melakukan upaya maksimal pencegahan pencemaran melalui pendekatan AMDAL dengan melaksanakan rencana pengelolaan lingkungan (RKL), rencana pemantauan lingkungan (RPL) dan pendekatan manajemen seperti audit lingkungan (Regulatory Complience Audit or Environmental Management System).

Kedua pendekatan tersebut dikategorikan telah memenuhi unsur A Certain Standard of Care. Untuk mengatasi perkembangan ini dikembangkan prinsip Strict Liability.

Kedua, Prinsip Strict Liability yang terdapat dalam pasal 88. Strict Liability dalam bahasa Indonesia diterjemahkan sebagai tanggungjawab mutlak, dapat pula diterjemahkan sebagai tanggungjawab seketika dan langsung, serta tanggungjawab terbatas. Diartikan dengan tanggungjawab seketika karena mengandung makna tanggungjawab tergugat harus dilaksanakan secara seketika dan langsung tanpa harus menunggu putusan pengadilan yang menetapkan tergugat bersalah. Adapun diartikan sebagai tanggungjawab terbatas karena dikaitkan dengan asuransi. Pihak asuransi akan menanggung kerugian secara terbatas yaitu sampai nilai asuransi yang dipertanggungkan. ${ }^{3}$

Pemberlakuan asas pertanggungjawaban mutlak (strict liability) pertama kali diperkenalkan di negara Inggris pada tahun 1868, pada kasus Ryland vs Fletcher. Keputusan Court of Exchequer Chamber menyatakan bahwa kegiatan atau aktivitas yang mengandung bahaya atau resiko, apabila mengakibatkan kerugian bagi orang lain, dianggap telah memenuhi unsur kesalahan. Penanggungjawab kegiatan tersebut hanya dapat dibebaskan dari pertanggungjawaban apabila ia dapat membuktikan bahwa kerugian yang timbul adalah akibat dari kesalahan pihak penggugat sendiri atau akibat bencana alam.

Dalam perkembangannya di banyak negara, prinsip tanggungjawab mutlak (strict liability), pengaturannya senantiasa dikaitkan dengan undang-undang

\footnotetext{
${ }^{3}$ Imamulhadi, Perkembangan Prinsip Strict Liability dan Precautionary Dalam Penyelesaian Sengketa Lingkungan Hidup di Pengadilan, Jurnal Mimbar Hukum Vol. 25, Nomor 3, Oktober 2013, hlm. 419
} 
lingkungan, mengingat lingkungan hidup merupakan sumber kehidupan manusia, binatang, tumbuhan dan makhluk hidup lainnya, maka upaya perlindungan lingkungan hidup merupakan prioritas yang harus dilakukan oleh seluruh umat manusia agar kelangsungan sistem kehidupan tetap terjaga. ${ }^{4}$

Di Indonesia pengaturan hukum mengenaistrict liability pertama kali diatur dalam Keputusan Presiden RI No. 18 Tahun 1978 tentang pengesahan "International Convention on Civil Liability for Oil Poluution Damage" dalam pasal 3 ayat (1) yang pada pokoknya sebagai berikut: ${ }^{5}$

1. Polluter (pelaku dalam hal ini pemilik) telah terbeban tanggung jawab saat kejadian itu timbul. Atau bila ternyata kecelakaan itu merupakan rangkaian kejadian, maka timbulnya tanggung jawab adalah saat kejadian pertama.

2. Setiap kerusakan yang timbul dari kecelakaan, harus dipertanggungjawabkan.

3. Dengan demikian, tanggung jawab tidaklah mendasarkan tuntutan atas tidaknya kesalahan.

Selanjutnya lebih jelas lagi dituangkan dalam Undang-Undang Nomor 4 Tahun 1982 Tentang Ketentuan-Ketentuan Pokok Pengelolaan Lingkungan Hidup yang merupakan tindak lanjut atas keikutsertaan Indonesia dalam Konferensi Lingkungan Hidup sedunia di Stockholm, Swedia. Pada undang-undang ini memberikan ketentuan mengenai tanggungjawab mutlak (strict liability) yang tercantum dalam pasal 21 yang isinyamenyatakan:

"Dalam beberapa kegiatan yang menyangkut jenis sumber daya tertent $u$ tanggungjawab timbul secara mutlak pada perusak dan atau pencemar pada saat terjadinya perusakan dan atau pencemaran lingkungan hidup yang pengaturannya diatur dalam peraturan perundang-undangan yang bersangkutan."

Dalam penjelasan pasal 21 tersebut menyatakan sebagai berikut:

"Tanggungjawab mutlak dikenakan secara selektif atas kasus yang akan ditetapkan berdasarkan peraturan perundang-undangan yang dapat menentukan jenis dan kategori kegiatan yang akan terkena oleh ketentuan yang dimaksud."

Dalam undang-undang ini terlihat bahwa pemerintah sangat berhati-hati dalam menerapkan prinsip tanggungjawab mutlak, bahwa pembalikan beban pembuktian atas kasus lingkungan hidup tidak mudah untuk dilakukan dan dilaksanakan bertahap sesuai dengan perkembangan pada masa itu.

\footnotetext{
${ }^{4}$ Sutoyo, Pengaturan Tanggung Jawab Mutlak (Strict Liability) Dalam Hukum Lingkungan, Jurnal Pendidikan Pancasila dan Kewarganegaraan, Th. 24, Nomor 1, Februari 2011, hlm. 58-59

${ }^{5}$ Syamsul Arifin dkk, Hukum Perlindungan dan Pengelolaan Lingkungan Hidup Di Indonesia (Medan: Perdana Publishing, 2018), hlm. 237
} 
Kemudian pada tahun 1997, terjadi pembaharuan terhadap peraturan mengenai lingkungan hidup yaitu dengan diundangkannya Undang-Undang Nomor 23 Tahun 1997 Tentang Pengelolaan Lingkungan Hidup. Mengenai asas tanggungjawab mutlak (strict liability) diatur dalam pasal 35 yang isinya sebagai berikut:

(1) Penanggungjawab usaha dan/atau kegiatan yang usaha dan kegiatannya menimbulkan dampak besar dan penting terhadap lingkungan hidup, yang menggunakan bahan berbahaya dan beracun, bertanggungjawab secara mutlak atas kerugian yang ditimbulkan, dengan kewajiban membayar ganti rugi secara langsung dan seketika pada saat terjadinya pencemaran dan/atau perusakan lingkungan hidup;

(2) Penanggungjawab usaha dan/atau kegiatan dapat dibebaskan dari kewajiban sebagaimana dimaksud pada ayat (1) jika yang bersangkutan dapat membuktikan bahwa pencemaran dan/perusakan lingkungan hidup disebabkan salah satu alasan dibawah ini:

a. Adanya bencana alam atau peperangan

b. Adanya keadaan terpaksa diluar kemampuan manusia

c. Adanya tindakan pihak ketiga yang menyebabkan terjadinya pencemaran dan/atau perusakan lingkungan hidup

Selanjutnya, pada tahun 2009 terjadi lagi pembaharuan tehadap peraturan mengenai lingkungan hidup yaitu dengan diundangkannya Undang-Undang Nomor 32 Tahun 2009 Tentang Perlindungan dan Pengelolaan Lingkungan Hidup (UUPPLH) yang merupakan pengganti atas Undang-Undang Nomor 23 Tahun 1997 Tentang Pengelolaan Lingkungan Hidup. Dalam undang-undang pengaturan tentang asas tanggungjawab mutlak (strict liability) mengalami perubahan. Hal ini dapat dilihat melalui pasal 88 yang isinya sebagai berikut:

"Setiap orang yang tindakannya, usahanya dan/atau kegiatannya menggunakan B3, menghasilkan dan/atau mengelola limbah B3 dan/atau yang menimbulkan ancaman serius terhadap lingkungan hidup, bertanggung jawab mutlak atas kerugian yang terjadi sepanjang kerugian tersebut disebabkan oleh yang bersangkutan"

Tanggungjawab mutlak dalam undang-undang ini dikaitkan dengan kegiatan yang berhubungan dengan bahan berbahaya dan beracun (B3). Dalam artian setiap kegiatan yang menggunakan, menghasilkan dan/atau mengelola limbah B3. Pengertian bahan berbahaya dan beracun (B3) diatur dalam pasal 1 ayat 21 yang isinya sebagai berikut:

"Bahan berbahaya dan beracun yang selanjutnya disingkat B3 adalah zat, energi, dan/atau komponen lain yang karena sifat, konsentrasi, dan/atau jumlahnya, baik secara langsung maupun tidak langsung, dapat mencemarkan dan/atau merusak lingkungan hidup, dan/atau membahayakan lingkungan hidup, kesehatan serta kelangsungan hidup manusia dan makhluk hidup lain" 


$\begin{array}{lll}\text { Lurnas } \mathscr{H} f \text { kum } & \text { P-ISSN } & : 2615-3416 \\ \text { Samudra Keadilan } & \text { E-ISSN } & : 2615-7845\end{array}$

Volume 15, Nomor 2, Juli-Desember 2020

Sedangkan pengertian limbah bahan berbahaya dan beracun (B3) diatur dalam pasal 1 ayat 22 yang isinya sebagai berikut: "Limbah bahan berbahaya dan beracun yang selanjutnya disebut Limbah B3 adalah sisa suatu usaha dan/atau kegiatan yang mengandung B3." Dalam penjelasan pasal 88 UUPPLH menyatakan bahwa yang dimaksud dengan bertanggungjawab mutlak atau strict liability adalah unsur kesalahan tidak perlu dibuktikan oleh pihak penggugat sebagai dasar pembayaran ganti rugi. Namun, pihak penggugat harus membuktikan kerugian yang dialami sebagai akibat dari perbuatan/kegiatan (membuktikan adanya kausalitas/ hubungan sebab akibat). Ketentuan ayat ini merupakan lex specialisdalam gugatan tentang perbuatan melanggar hukum pada umumnya. Besarnya nilai ganti rugi yang dapat dibebankan terhadap pencemar atau perusak lingkungan hidup menurut pasal ini dapat ditetapkan sampai batas tertentu. Yang dimaksud dengan "sampai batas waktu tertentu" adalah jika menurut penetapan peraturan perundangundangan ditentukan keharusan asuransi bagi usaha dan/atau kegiatan yang bersangkutan atau telah tersedia dana lingkungan hidup.

Dengan adanya ketentuan mengenai strict liability ini membawa keuntungan bagi pihak korban dalam memintai pertanggungjawaban dari pelaku (polluter) karena dengan perkembangan teknologi dan kebutuhan saat ini pemanfaatan sumberdaya alam akan semakin tinggi banyak masyarakat yang menjadi korban pencemaran lingkungan. Ketentuan ini juga menjadi peringatan terhadap pelaku usaha yang mengolah limbah B3 agar semakin berhati-hati dan mengikuti aturan pemerintah.

\section{Kewenangan PEMPROV SUMUT Terkait Penerapan Asas Tanggung Jawab Mutlak Berdasarkan UU No.32 Tahun 2009}

Menurut KBBI, kewenangan merupakan hak dan kekuasaan untuk bertindak, kekuasaan membuat keputusan, memerintah dan melimpahkan tanggungjawab kepada orang/badan lain. Kewenangan sering dihubungkan dengan kekuasaan yang diperoleh berdasarkan ketentuan hukum. Secara umum kewenangan tersebut dapat diperoleh melalui 3 cara yaitu:

1. Atribusi

Pasal 1 angka 22 UU No 30 Tahun 2014 tentang Administrasi Pemerintahan menjelaskan bahwa yang dimaksud dengan atribusi adalah pemberian kewenangan kepada badan dan/atau pejabat pemerintahan oleh Undang-Undang Dasar Negara Republik Indonesia Tahun 1945 atau Undang-Undang.

2. Delegasi

Pasal 1 angka 23 UU No 30 Tahun 2014 tentang Administrasi Pemerintahan menjelaskan bahwa yang dimaksud dengan delegasiadalah pelimpahan kewenangan dari badan dan/atau pejabat pemerintahan yang lebih tinggi kepada badan dan/atau pejabat pemerintahan yang lebih rendah dengan tanggung jawab dan tanggung gugat beralih sepenuhnya kepada penerima delegasi. 


\section{Mandat}

Pasal 1 angka 24 UU No 30 Tahun 2014 tentang Administrasi Pemerintahan menjelaskan bahwa yang dimaksud dengan mandat adalahpelimpahan kewenangan dari badan dan/atau pejabat pemerintahan yang lebih tinggi kepada badan dan/atau pejabat pemerintahan yang lebih rendah dengan tanggung jawab dan tanggung gugat tetap berada pada pemberi mandat.

Mengenai kewenangan dalam mengelola lingkungan hidup, Undang-Undang No. 32 Tahun 2009 tentang Perlindungan dan Pengelolaan Lingkungan Hidup selanjutnya disebut UUPPLH telah memberikan kewenangan yang sangat luas kepada pemerintah daerah dalam melakukan perlindungan dan pengelolaan lingkungan hidup di daerah masing-masing. Hal ini sesuai dengan ketentuan pasal 18 Undang-Undang Dasar Negara Republik Indonesia Tahun 1945 yang pada intinya bahwa NKRI dibagi atas daerah provinsi dan kabupaten/kota dimana daerah provinsi dankabupaten/kota tersebut diberikan kewenangan untuk mengurus dan mengatur sendiri urusan pemerintahannya berdasarkan asas otonomi dan tugas pembantuan, kecuali urusan pemerintahan yang oleh undang-undang diatur sebagai urusan pemerintah pusat. Oleh karenanya pemerintah provinsi dan pemerintah kabupaten/kota dapat membentuk kelembagaan pengelolaan lingkungan hidup yang mempunyai kewenangan untuk mengelola dan menilai mengenai lingkungan di daerah masing-masing.

Dalam hal ini Pemerintah Provinsi Sumatera Utara (PEMPROVSU) memiliki kewenangan dalam mengelola lingkungan hidup yang di delegasikan kepada Dinas Lingkungan Hidup Provinsi Sumatera Utara sebagai instansi atau organ pelaksana. Dalam Peraturan Gubernur Sumatera Utara No. 33 Tahun 2017 tentang Tugas, Fungsi, Uraian Tugas dan Tata Kerja Dinas Lingkungan Hidup Provinsi Sumatera Utara pada pasal 2 ayat (1) mengatur bahwa Dinas Lingkungan Hidup Provinsi Sumatera Utara mempunyai tugas melaksanakan urusan lingkungan hidup yang menjadi kewenangan provinsi di bidang administrasi umum, pengkajian tata lingkungan, pengelolaan bahan limbah berbahaya dan beracun, persampahan, pengendalian pencemaran lingkungan dan kerusakan lingkungan hidup, penataan dan peningkatan kapasitas lingkungan hidup dan tugas-tugas dekonsentrasi dan pembantuan. Selanjutnya dalam ayat (2), adapun Dinas Lingkungan Hidup Provinsi Sumatera Utara menyelenggarakan fungsi:

1. Penyelenggaraan perumusan kebijakan perencanaan lingkungan hidup, kajian lingkungan hidup strategis, pengendalian pencemaran dan/atau kerusakan lingkungan hidup, keanekaragaman hayati, limbah bahan berbahaya beracun, pembinaan dan pengawasan terhadap izin lingkungan, izin perlindungan dan pengelolaan lingkungan hidup sesuai dengan lingkup tugasnya;

2. Penyelenggaraan kebijakan perencanaan lingkungan hidup, kajian lingkungan hidup strategis, pengendalian pencemaran dan/atau kerusakan lingkungan hidup, keanekaragaman hayati, limbah bahan berbahaya beracun, pembinaan dan pengawasan terhadap izin lingkungan, izin perlindungan dan pengelolaan lingkungan hidup sesuai dengan lingkup tugasnya; 
3. Penyelenggaraan evaluasi dan pelaporan perencanaan lingkungan hidup, kajian lingkungan hidup strategis, pengendalian pencemaran dan/atau kerusakan lingkungan hidup, keanekaragaman hayati, limbah bahan berbahaya beracun, pembinaan dan pengawasan terhadap izin lingkungan, izin perlindungan dan pengelolaan lingkungan hidup sesuai dengan lingkup tugasnya;

4. Penyelenggaraan administrasi perencanaan lingkungan hidup, kajian lingkungan hidup strategis, pengendalian pencemaran dan/atau kerusakan lingkungan hidup, keanekaragaman hayati, limbah bahan berbahaya beracun, pembinaan dan pengawasan terhadap izin lingkungan, izin perlindungan dan pengelolaan lingkungan hidup sesuai dengan lingkup tugasnya;

5. Penyelenggaraan tugas lain yang diberikan oleh Gubernur terkait tugas dan fungsinya.

Dari beberapa fungsi tersebut dapat disimpulkan bahwa Dinas Lingkungan Hidup Provinsi Sumatera Utara memiliki kewenangan dalam mengintervensi pengendalian pencemaran dan/atau kerusakan lingkungan hidup serta mengurusi limbah bahan berbahaya dan beracun (B3) di Provinsi Sumatera Utara. Dalam UUPPLH Pasal 63 ayat (2) juga telah menyebutkan bahwa kewenangan pemerintah provinsi salah satunya adalah melakukan penegakan hukum lingkungan hidup pada tingkat provinsi (huruf s). Penegakan hukum lingkungan tersebut dapat dilakukan dengan menjatuhkan sanksi administratif, gugatan perdata maupun penjatuhan pidana.

Didalam pasal 90 UU No. 32 Tahun 2009 mengatur tentang hak gugat pemerintah dan pemerintah daerah yang berisi:

(1) Instansi pemerintah dan pemerintah daerah yang bertanggungjawab di bidang lingkungan hidup berwenang mengajukan gugatan ganti rugi dan tindakan tertentu terhadap usaha dan/atau kegiatan yang menyebabkan pencemaran dan/atau kerusakan lingkungan hidup yang mengakibatkan kerugian lingkungan hidup.

(2) Ketentuan lebih lanjut mengenai kerugian lingkungan hidup sebagaimana dimaksud pada ayat (1) diatur dengan Peraturan Menteri.

Di dalam penjelasannya disebutkan bahwa gugatan ganti rugi tersebut adalah untuk sebuah kerugian yang timbul sebagai akibat dari pencemaran dan/atau perusakan lingkungan hidup yang bukanmerupakan hak milik privaat. Ini berarti kerugian yang terjadi sebagai akibat pencemaran dan/atau perusakan tersebut harus dialami oleh hak milik publik (bukan hak milik privaat). Jadi apabila ada aset/ sumber daya alam yang ada di Sumatera Utara tercemar oleh adanya usahadan/atau kegiatan dari pelaku usaha maka Pemerintah Provinsi Sumatera Utara mempunyai kewenangan untuk menggugat ganti rugi.

Dalam pengajuan gugatan terhadap pencemaran lingkungan hidup, di dalam Undang-Undang No. 32 Tahun 2009 ditetapkan tenggang kadaluwarsa untuk pengajuan gugatan, sebagaimana diatur dalam pasal 89 sebagai berikut: 
Volume 15, Nomor 2, Juli-Desember 2020

1. Tenggat kedaluwarsa untuk mengajukan gugatan ke pengadilan mengikuti tenggang waktu sebagaimana diatur dalam ketentuan Kitab Undag-Undang Hukum Perdata dan dihitung sejak diketahui adanya pencemaran dan/atau kerusakan lingkungan hidup

2. Ketentuan mengenai tenggat kedaluwarsa tidak berlaku terhadap pencemaran dan/atau kerusakan lingkungan hidup yang disebabkan oleh usaha dan/atau kegiatan yang menggunakan dan/atau mengelola B3 serta menghasilkan dan/atau mengelola limbah $B 3$.

Pertanggungjawaban mutlak (strict liability) ini dibatasi hanya kepada kegiatan yang menggunakan B3, menghasilkan dan/atau mengelola limbah B3 dan/atau yang menimbulkan ancaman serius terhadap lingkungan hidup. Adapun jumlah usaha yang terdata dalam pengelolaan limbah B3 di wilayah Provinsi Sumatera Utara dapat dilihat dalam tabel dibawah ini:

Tabel 1.

Jumlah Usaha Yang Mengelola B3 dan/atau Limbah B3 di Provinsi Sumatera Utara Tahun 2019

\begin{tabular}{|c|c|c|}
\hline No. & Kabupaten/Kota & $\begin{array}{c}\text { Jumlah Usaha Yang Mengelola B3 } \\
\text { dan/atau Limbah B3 }\end{array}$ \\
\hline 1 & Medan & 85 \\
\hline 2 & Deli Serdang & 72 \\
\hline 3 & Langkat & 22 \\
\hline 4 & SerdangBedagai & 19 \\
\hline 5 & Simalungun & 32 \\
\hline 6 & Asahan & 35 \\
\hline 7 & Karo & 5 \\
\hline 8 & Dairi & 2 \\
\hline 9 & Labuhanbatu Utara & 27 \\
\hline 10 & Labuhanbatu & 3 \\
\hline 11 & Toba Samosir & 1 \\
\hline 12 & Tapanuli Utara & 10 \\
\hline 13 & Tapanuli Tengah & 1 \\
\hline 14 & HumbangHasundutan & 6 \\
\hline 15 & Tapanuli Selatan & 5 \\
\hline 16 & Mandailing Natal & \\
\hline & & \\
\hline
\end{tabular}




\begin{tabular}{|c|c|c|}
\hline 17 & Padanglawas & 9 \\
\hline 18 & Sibolga & 3 \\
\hline & Total & $\mathbf{3 5 3}$ \\
\hline
\end{tabular}

Sumber Data: http://plb3.menlhk.go.id/siraja-limbah-2019/

Berdasarkan data yang diperoleh melalui website Siraja Limbah sampai dengan tahun 2019, jumlah usaha yang mengelola B3 dan/atau limbah B3 di Provinsi Sumatera Utara ada sebanyak 353 usaha. Daerah yang memiliki usaha terbanyak berada di Kota Medan dengan jumlah usaha sebanyak 85 usaha. Data ini belum termasuk usaha-usaha lain yang belum/tidak mendaftarkan usahanya di website tersebut.

Berdasarkan hasil wawancara dengan salah satu Pejabat di Dinas Lingkungan Hidup Provinsi Sumatera Utara, Dinas Lingkungan Hidup Provinsi Sumatera Utara belum pernah melakukan gugatan atas pencemaran lingkungan hidup dengan menggunakan asas strict liability. Hal ini disebabkan oleh beberapa hal. Pertama, pembuktian B3 dan/atau limbah B3 yang tidak sederhana. Dalam pembuktian apakah suatu benda yang mencemari lingkungan merupakan B3 dan/atau limbah B3 harus mengikuti beberapa prosedur tertentu. Dalam Peraturan Menteri Lingkungan Hidup dan Kehutanan Republik Indonesia Nomor P.10/MENLHK/SETJEN/PLB.3/4/2020 tentang Tata Cara Uji Karakteristik dan Penetapan Status Limbah Bahan Berbahaya dan Beracun mengatur tentang prosedurprosedur uji karakteristik limbah B3 dan penetapan limbah B3. Benda-benda tersebut harus melalui Uji Toksikologi Lethal Dose-50 untuk mengukur hubungan dosis-respon antara limbah B3 dengan kematian hewan uji yang menghasilkan 50\% respon kematian pada populasi hewan uji. Oleh karenanya penentuan status B3 dan/atau limbah B3 memerlukan waktu yang cukup panjang ditambah lagi laboratorium untuk pengujian tersebut belum tersedia di wilayah Sumatera Utara, hanya tersedia di Serpong, Tangerang Selatan.

Kedua, kurang memadainya sumber daya manusia (SDM) di Dinas Lingkungan Hidup Provinsi Sumatera Utara baik dari segi kuantitas maupun segi kualitas. Dari segi kuantitas, dari 353 jumlah usaha di Provinsi Sumatera Utara yang usahanya menggunakan B3, menghasilkan dan/atau mengelola limbah B3 tidak sebanding dengan pejabat pengawas yang dimiliki yaitu hanya sekitar 10 orang saja. Sehingga pengawasan terhadap usaha-usaha ini tidak dapat dilakukan secara menyeluruh. Belum lagi usahausaha yang tidak didaftarkan di website Siraja Limbah. Tentunya hal ini akan mempersulit penerapan asas strict liability bagi usaha-usaha yang dapat dimintai pertanggungjawaban mutlak. Akhirnya, penindakan terhadap pelaku pencemaran lingkungan hidup tidak dapat berjalan secara efektif hanya menunggu pengaduan dari warga. Kemudian dari segi kualitas SDM, hanya sedikit pejabat di Dinas Lingkungan Hidup Provinsi Sumatera Utara yang menguasai UUPPLH khususnya dalam penerapan asas strict liability bagi usaha yang menurut pasal 88 dapat dimintai pertanggungjawaban mutlak. Ketentuan ayat ini merupakan lex specialis dalam gugatan tentang perbuatan melanggar hukum pada umumnya. 
Ketiga, kurangnya ketersediaan anggaran yang dialokasikan untuk melakukan penegakan hukum lingkungan di Dinas Lingkungan Hidup Provinsi Sumatera Utara. Seperti yang telah diuraikan sebelumnya penerapan asas strict liability tidak serta merta dapat diterapkan. Meskipun tidak usah lagi membuktikan adanya unsur kesalahan, penggugat juga harus membuktikan subjeknya dan membuktikan apakah benda yang mencemari lingkungan tersebut merupakan B3 dan/atau limbah B3. Pembuktian tersebut hanya dapat dilakukan di laboratorium yang berada di daerah Serpong, Tangerang Selatan. Oleh karenanya, proses pembuktian tersebut memerlukan biaya yang berlebih. Berdasarkan data yang diperoleh melalui Dinas Lingkungan Hidup Provinsi Sumatera Utara, APBD tahun 2018 Pemprov Sumut mengalokasikan sebesar Rp. 25.708.089.785,(dua puluh lima milyar tujuh ratus delapan puluh juta delapan puluh sembilan ribu tujuh ratus delapan puluh lima rupiah) kepada Dinas Lingkungan Hidup. Dari Rp. 25.708.089.785 tersebut, program pengendalian pencemaran dan perusakan lingkungan hidup hanya mendapat Rp. 399.984.198 (tiga ratus sembilan puluh sembilan juta sembilan ratus delapan puluh empat ribu seratus sembilan puluh delapan rupiah) atau hanya berkisar $1,5 \%$ dari total anggaran keseluruhan dengan rincian

Dengan kondisi yang ada, Dinas Lingkungan Hidup Provinsi Sumatera Utara lebih mengedepankan sanksi administratif sebagaimana yang juga diatur dalam Pasal 76-83 UUPPLH. Sanksi administratif tersebut dapat berupa teguran tertulis, paksaan pemerintah, pembekuan izin lingkungan atau pencabutan izin lingkungan. Di bidang perdata, Dinas Lingkungan Hidup Provinsi Sumatera Utara telah beberapa kali menyelesaikan sengketa lingkungan hidup. Akan tetapi semua sengketa tersebut berhasil diselesaikan di luar pengadilan. Penyelesaian sengketa diluar pengadilan merupakan mekanisme penyelesaian sengketa yang juga diatur dalam pasal 84 dan 85 UUPPLH. Adapun pilihan penyelesaian sengketa lingkungan hidup dilakukan secara sukarela oleh pihak yang bersengketa. Di pengadilan pun apabila ada perkara perdata yang masuk ke pengadilan, sesuai dengan Perma No. 1 Tahun 2016 tentang Mediasi maka sengketa tersebut diwajibkan untuk dilakukan mediasi. Penyelesaian sengketa lingkungan hidup dengan mediasi pada pokoknya untuk mencapai kesepakatan mengenai bentuk dan besarnya ganti rugi, tindakan pemulihan akibat pencemaran dan/atau perusakan, tindakan tertentu untuk menjamin tidak akan terulangnya pencemaran dan/atau perusakan serta tindakan untuk mencegah timbulnya dampak negatif terhadap lingkungan hidup. Selanjutnya, besarnya kerugian lingkungan hidup diatur dalam Peraturan Menteri Lingkungan Hidup Republik Indonesia Nomor 7 Tahun 2014 Tentang Kerugian Lingkungan Hidup Akibat Pencemaran dan/ atau Kerusakan Lingkungan Hidup.Berbicara mengenai penentuan ganti kerugian lingkungan hidup, dalam hukum positif pedoman penentuan besaran ganti kerugian lebih lanjut diatur dalam Peraturan Menteri Lingkungan Hidup Nomor 7 Tahun 2014 Tentang Kerugian Lingkungan Hidup Akibat Pencemaran dan/atau Kerusakan Lingkungan Hidup. Dalam permen tersebut dijelaskan bahwa perhitungan besaran ganti rugi dipengaruhi oleh faktor teknis dan non-teknis.Faktor teknis antara lain: durasi waktu atau lama terjadinya Pencemaran dan/atau Kerusakan Lingkungan Hidup, volume polutan yang melebihi Baku Mutu Lingkungan Hidup, parameter polutan yang melebihi Baku Mutu Lingkungan Hidup, luasan lahan dan 


$\begin{array}{lll}\text { Lurnas Ffukum } & \text { P-ISSN } & : 2615-3416 \\ \text { Samudra Keadilan } & \text { E-ISSN } & : 2615-7845\end{array}$

Volume 15, Nomor 2, Juli-Desember 2020

sebaran Pencemaran dan/ atau Kerusakan Lingkungan Hidup; dan/atau status lahan yang rusak. Sedangkan faktor nonteknis antara lain; inflasi; dan/atau kebijakan pemerintah.

\section{Penutup}

\section{A. Kesimpulan}

Adapun yang menjadi kesimpulan adalah sebagai berikut:

Prinsip Strict Liability (pertanggungjawaban mutlak) merupakan prinsip pertanggungjawaban dimanaunsur kesalahan tidak perlu dibuktikan oleh pihak penggugat sebagai dasar pembayaran ganti rugi. Namun, pihak penggugat harus membuktikan kerugian yang dialami sebagai akibat dari perbuatan/kegiatan (membuktikan adanya kausalitas/ hubungan sebab akibat). Ketentuan ayat ini merupakan lex specialisdalam gugatan tentang perbuatan melanggar hukum pada umumnya.

Pemerintah Provinsi Sumatera Utara memiliki kewenangan dalam mengajukan gugatan secara strict liability(prinsip tanggungjawab mutlak) bagi pelaku perusakan dan/atau pencemaran lingkungan hidup. Merujuk dalam pasal 90 UUPPLH yang mengatur tentang hak gugat instansi pemerintah dan pemerintah daerah. Namun terdapat beberapa kendala yang dialami oleh Dinas Lingkungan Hidup Provinsi Sumatera Utara yakni pembuktian B3 dan/atau limbah B3 yang tidak sederhana, kurang memadainya sumber daya manusia (SDM) baik dari segi kuantitas maupun segi kualitas dan kurangnya ketersediaan anggaran yang dialokasikan untuk melakukan penegakan hukum lingkungan di Sumatera Utara.

\section{B. Saran}

Adapun yang menjadi saran adalah sebagai berikut:

Diperlukan adanya pembaharuan peraturan-peraturan tentang penegakan hukum lingkungan khususnya gugatan perdata secara strict liability (tanggungjawab mutlak) demi menjamin keadilan, kepastian dan kemanfaatan hukum.

Diperlukan adanyaperhatian pemerintah berupa dukungan penganggaran bagi proses penegakan hukum lingkungan yang dilakukan oleh Dinas Lingkungan Hidup Provinsi Sumatera Utara serta pengadaan laboratorium yang memungkinkan B3 dan/atau limbah B3 dapat dilakukan pengujian dan penentuan di Sumatera Utara. Selanjutnya, penambahan personil pengawas yang ada di Dinas Lingkungan Hidup Provinsi Sumatera Utara agar pengawasan dapat berjalan lebih efektif serta diperlukan kegiatan-kegiatan untuk memperdalam pengetahuan hukum baik berupa pelatihan atau penyuluhan hukum mengenai penegakan hukum lingkungan khususnya dalam menerapkan asas strict liability bagi personil di Dinas Lingkungan Hidup Provinsi Sumatera Utara. 


\section{Daftar Pustaka}

Arfin, Syamsul dkk, Hukum Perlindungan dan Pengelolaan Lingkungan Hidup Di Indonesia, Medan: Perdana Publishing. 2018

Lubis, M. Solly,FilsafatHukumdanPenelitian,Bandung:CV.MandarMaju, 1994.

Imamulhadi, Perkembangan Prinsip Strict Liability dan Precautionary Dalam Penyelesaian Sengketa Lingkungan Hidup di Pengadilan, Jurnal Mimbar Hukum Vol. 25, Nomor 3, Oktober 2013

Sutoyo, Pengaturan Tanggung Jawab Mutlak (Strict Liability) Dalam Hukum Lingkungan, Jurnal Pendidikan Pancasila dan Kewarganegaraan, Th. 24, Nomor 1, Februari 2011

Undang-Undang Dasar Negara Republik Indonesia Tahun 1945

Undang-Undang Nomor 4 Tahun 1982 Tentang Ketentuan-Ketentuan Pokok Pengelolaan Lingkungan Hidup

Undang-Undang Nomor 23 Tahun 1997 Tentang Pengelolaan Lingkungan Hidup

Undang-Undang Nomor 32 Tahun 2009 Tentang Perlindungan dan Pengelolaan Lingkungan Hidup (UUPPLH) yang merupakan pengganti atas Undang-Undang Nomor 23 Tahun 1997 Tentang Pengelolaan Lingkungan Hidup

Undang-Undang No 30 Tahun 2014 tentang Administrasi Pemerintahan

Peraturan Gubernur Sumatera Utara No. 33 Tahun 2017 tentang Tugas, Fungsi, Uraian Tugas dan Tata Kerja Dinas Lingkungan Hidup Provinsi Sumatera Utara

Peraturan Menteri Lingkungan Hidup dan Kehutanan Republik Indonesia Nomor P.10/MENLHK/SETJEN/PLB.3/4/2020 tentang Tata Cara Uji Karakteristik dan Penetapan Status Limbah Bahan Berbahaya dan Beracun

Peraturan Menteri Lingkungan Hidup Republik Indonesia Nomor 7 Tahun 2014 Tentang Kerugian Lingkungan Hidup Akibat Pencemaran dan/ atau Kerusakan Lingkungan Hidup.

Siraja Limbah, http://plb3.menlhk.go.id/siraja-limbah-2019/, 12 November 2020

Wikipedia, https://id.wikipedia.org/wiki/Sumatra_Utara, 01 Desember 2020

Walhi Sumut, https://www.walhi.or.id/walhi-sumut-hari-lingkungan-hidup-seduniapilgubsu-terburuk-sepanjang-periode, 02 Desember 2020 